\begin{tabular}{c}
\hline Review of \\
ECONOMICS \\
and \\
INSTITUTIONS
\end{tabular}

\title{
International Patenting, Patent Rights, and Technology Gaps
}

\author{
Walter G. Park $\bowtie$ \\ American University
}

\begin{abstract}
International patenting activity is a source of international technology diffusion. However, technology diffuses imperfectly and technology gaps exist between nations. Indeed patenting activity is largely concentrated in developed countries. A gap also exists in patent protection levels across countries, being weak in largely developing countries. Hence this paper studies the extent to which the strengthening and harmonization of patent rights would stimulate international patenting and help narrow technology gaps. International total factor productivity (TFP) differences are used as measures of technology gaps. The paper develops and estimates a model of international patenting and TFP behavior using a panel data set of 44 countries, developed and developing, over the period 1975 - 2005. Of these countries, 25 of them will serve as 'source countries' (i.e., the source of technologies). Overall, however, the paper finds that international patent reforms (even those that involve major regime changes) have relatively modest effects on the technology gap between developed and developing nations.
\end{abstract}

JEL classification: 011; 033; 034; 043

Keywords: international technology diffusion, patents, intellectual property rights, total factor productivity, and developing economies

I would like to thank Michael Ferrantino, Juan Carlos Ginarte, Bronwyn Hall, Rose Marie Ziedonis, Sam Kortum, Greg Linden, Kristina Lybecker, Mark Schankerman, Maurice Shiff, and Brian Wright for helpful comments and discussions. I would also like to thank Jessica Duda for capable research assistance, and Lise McLeod (WIPO) for data and technical advice. I remain fully responsible for all errors and/or omissions.

$\triangle$ Address: Department of Economics, American University, Washington, D.C. 20016. (Phone: +1 202-885-3774, Fax: +1 202-885-3790 WGP@American.Edu).

\section{Recommended Citation}

Park, W.G. (2013). International Patenting, Patent Rights, and Technology Gaps. Review of Economics and Institutions, 4(1), Article 3. doi: 10.5202/rei.v4i1.104. Retrieved from http://www.rei.unipg.it/rei/article/view/104 


\section{Introduction}

This paper studies the extent to which international technology gaps are due to differences in patent protection levels and patenting activity across countries. The purpose is to determine whether international patent reform could help substantively narrow technology gaps between countries. The premise behind this is the notable role assigned to patent rights in affecting technology creation and diffusion. This study builds on recent work which emphasizes that technological progress depends on both domestic and foreign stocks of knowledge ${ }_{1}^{1}$ and that international patenting activity is an important channel for international knowledge capital diffusion and an important source of international knowledge spillovers, as inventors publicly disclose technical information in exchange for patent protection.2 $]^{3}$

However, as Fagerberg (1994) and Keller (2004) point out, global technology gaps can arise because not all countries share the same pool of knowledge. International technology diffusion is neither uniform nor complete: technology flows from a particular country may be greater to one country than to another and reach only a limited number of countries. This is reflected in the international patenting data: international patenting flows tend to be concentrated among developed economies, and relatively few, if any, patents are filed in less developed economies. To the extent that weak patent rights inhibit patenting, weak patent rights act as a barrier to technology diffusion and to reducing international technology gaps.

To determine the extent to which international technology gaps can be attributed to weak and divergent patent protection levels across countries, two issues need to be addressed: (a) the extent to which patenting activity is sensitive to levels of patent protection; (b) the extent to which international patenting contributes to domestic total factor productivity (TFP). The idea here is that domestic TFP depends on both domestic and foreign patent knowledge capital. The extent to which stronger patent rights stimulate international patenting, and the extent to which patentable ideas contribute to TFP, together determine the effects of patent rights on TFP. The paper then examines the distribution of TFP and patentable ideas among countries in order to assess the effects of stronger, more harmonized patent systems on global technology gaps.

In doing so, this paper makes two contributions to the literature: the first is to help explain international patenting behavior. There is little understanding thus far of its determinants. For instance, how important is patent protection given other incentives to patent (such as market size, costs of patenting, and so forth)? Bosworth (1984) finds that patent law dif-

\footnotetext{
1 See, for example, Bayoumi et. al. (1999), Park (1995), and Rivera and Batiz-Romer (1991).

2 See, for example, Eaton and Kortum (1996) and Sherwood (1991).

3 That is, patent owners have exclusive rights over the use of the invention, but they cannot prevent others from freely utilizing the knowledge revealed.
} 
ferences across countries insignificantly explain patenting to and from the U.K., while Eaton and Kortum (1996) find that strong patent protection does significantly stimulate patenting within the OECD. In contrast to these studies, this paper includes both developed and developing countries in its sample and employs a different measure of patent protection, one that varies over time as well as across countries. The time-series data help capture changes in patent law over time (as laws have changed for certain countries).

The second contribution is to provide empirical analyses on issues relevant to the North ws. South debate over the consequences of stronger global patent protection. $]^{4}$ Would stronger global standards widen the gap between the rich and poor, or enable the poorer to catch up? The question is controversial because while proponents of international patent reform would argue that developing nations would better stimulate domestic innovation and attract foreign technology, opponents would argue that imitation is also an important means of technological catch-up, and that stronger patent rights might deter economic development. Indeed, various studies have characterized imitation and innovation activities as alternative paths to development, where early on (in the development phase) lax patent rights may be a beneficial economic strategy. ${ }^{5}$ Despite these controversies, there is as yet no evidence on the role patent rights play in North-South technology gaps.

The paper is organized as follows: section 2 provides a theoretical model of international patenting and of its effects on total factor productivity (TFP). This section derives the two key equations that are to be estimated. Section 3 describes the data, and sections 4 and 5 present empirical results of the international patenting equation and TFP equation respectively. Section 6 presents simulations of the effects of international patent reform on technology gaps, and section 7 concludes. Overall, international patent reforms are found to reduce the spread in TFP (and in the share of global technology) between developed and developing countries only marginally.

\section{Theoretical Framework}

\subsection{International Patenting Behavior}

Assume an $N$ country world. The objective here is to determine the quantity of patents that will be filed by inventors of country $j$ in some country $n$. The case where $j=n$ refers to domestic patent applications, and $j \neq n$ to foreign patent applications. The country from which patents originate is

4 See Diwan and Rodrik (1991), Helpman (1993), Taylor (1994), Weiss (2010) for theoretical analyses, and Maskus (2012) for a richer survey of the literature.

5 See, for example, Connolly (1997) and van Elkan (1996). 
the source country, and the country to which patents are filed is the destination country.

Assume that in the $j$-th source country there are $Q_{j}$ patentable inventions. Let $q_{j}=1,2, \ldots, Q_{j}$ denote the quality of these inventions in ascending order; that is, invention 1 is of a lower quality than invention 2 , which in turn is of a lower quality than invention 3, and so forth. Some, all, or none of these $Q_{j}$ inventions may be patented at home or abroad. The variations in international patenting depend on three kinds of heterogeneity: 1) market heterogeneities (some destinations are more attractive than others); 2) invention heterogeneities (some inventions are more valuable than others); 3) heterogeneity between source countries (some source countries are more inventive than others).

To determine the extent of patenting between a given pair of source and destination countries, the focus will be on the first two kinds of heterogeneity. To begin, note that an inventor will seek patent protection if the net benefit of patenting exceeds the cost of filing for protection - say,

$$
\Delta V=V^{P A T}-V^{N O P A T} \geq c
$$

where $V^{P A T}$ and $V^{N O P A T}$ denote the value of a firm with and without patent protection respectively, and $c$ the cost of filing a patent. The underlying logic is that inventors have means other than patent protection to appropriate the rewards from their innovation (such as lead times, reputation, secrecy). Thus the value of a patent is the incremental return an inventor can get above and beyond that which can be realized by alternative (non-patenting) means.

To be more concrete, let $\pi_{n}\left(q_{j}\right)$ be the instantaneous flow of profits to the $q$-th invention from country $j$ that is exploited in market $n$ (again, if $j=n$, the invention is being exploited in the home market). The profits are a function of invention quality, which in turn depends on where the invention is from (hence the reason $q$ is indexed by $j$ ). For simplicity, assume that this function is linear; that is, $\pi_{n}\left(q_{j}\right)=q_{j} \bar{\pi}_{n}$, where $\bar{\pi}_{n}$ is some base level of profits (depending on market size). Each firm also faces hazards of imitation in market $n$. Assume that imitation acts like a tax on profits, and denote by $h$ the rate at which profits are appropriated by imitation. Thus net instantaneous profits are:

$$
\pi_{n}^{\prime}\left(q_{j}\right)=q_{j} \bar{\pi}_{n}\left(1-h\left(\theta_{n}\right)\right), \quad 0 \leq h \leq 1
$$

where $h$ is a function of $\theta_{n}$, an index of the strength of patent protection in market $n$ (with derivative $h^{\prime}\left(\theta_{n}\right)<0$ ). Assume that $\theta_{n} \in\left[0, \theta_{\text {max }}\right]$, where $\theta_{n}=0$ corresponds to the case of no patent laws and $\theta_{n}=\theta_{\max }$ to that where patent laws are as strong as possible (corresponding to say some international standard). Note that $h\left(\theta_{\max }\right)$ need not equal 0 nor $h(0)$ equal 1 ; that is, patent protection and imitation may both be imperfect. Assume that if 
patent protection is not obtained in market $n$, the benchmark imitation rate is $h=\bar{h}_{n}$.

The value of invention $q_{j}$ with a patent in market $n$ is the presented discounted value of the future stream of profits:

$$
V_{n}\left(q_{j}\right)=\int_{0}^{\infty} e^{-r t} \pi_{n}^{\prime}\left(q_{j}\right) \mathrm{d} t=\frac{q_{j} \bar{\pi}_{n}\left(1-h\left(\theta_{n}\right)\right)}{r},
$$

where $r$ is the real interest rate. Without a patent, the value of invention $q_{j}$ is the above expression with $h\left(\theta_{n}\right)$ replaced by $\bar{h}_{n}$. That is, a patent in market $n$ enables the patentee to 'purchase' a reduction in the incidence of imitation, the benefit from which is reflected in an increase in firm value:

$$
\Delta V_{n}\left(q_{j}\right)=V_{n}\left(q_{j}\right)^{P A T}-V_{n}\left(q_{j}\right)^{N O P A T}=\frac{q_{j} \bar{\pi}_{n}\left(\bar{h}_{n}-h\left(\theta_{n}\right)\right)}{r} .
$$

Given the cost of obtaining a patent in market $n$ (denoted by $c_{n}$ ), the $q$-th inventor from source country $j$ will patent in market $n$ if $\Delta V_{n}\left(q_{j}\right)>c_{n}$. Thus equation (2) helps identify factors which matter to the patenting decision; namely, market size (as reflected in the basic level of profits $\bar{\pi}_{n}$ ), level of patent rights $\theta_{n}$, cost of patenting $c_{n}$, invention quality $q_{j}$, and imitative capacity of local agents, as reflected in $\bar{h}_{n}$. The greater their imitative capacity, the greater the incentive of the inventor to patent and prevent the misappropriation of profits.

The critical quality level for country $j^{\prime}$ s inventions in market $n$ is $q_{j n}^{*}=$ $r \cdot c_{n} /\left(\bar{\pi}_{n}\left(\bar{h}_{n}-h\left(\theta_{n}\right)\right)\right)$, obtained by equating $\Delta V_{n}\left(q_{j}\right)$ and $c_{n}$. Only inventions whose quality levels exceed this critical level are patented in market $n$. The higher the cost of patenting, the higher the critical cutoff quality $q_{j n}^{*}$; in other words, fewer (and higher quality) inventions are worth patenting. The stronger the level of patent protection or the larger the market size, the lower the critical cutoff. Thus, the critical quality level $q_{j n}^{*}$ is a function of market $n$ 's characteristics - that is, $q_{j n}^{*}=q_{j n}^{*}\left(x_{n}\right)$, where $x_{n}$ is some weighted aggregate of "market fundamentals" (such as market size, patent protection level, imitative capacity, and patent filing costs).

Given $q_{j n}^{*}$, the quantity of patent applications from country $j$ in country $n$ - denoted by $P_{j n}$ - can be predicted. All $q_{j} \in\left[q_{j n}^{*}, Q_{j}\right]$ are patented in market $n$ and $q_{j} \in\left[1, q_{j n}^{*}\right)$ are not. That is,

$$
P_{j n}=Q_{j}-q_{j n}^{*}=Q_{j}-q_{j n}^{*}\left(x_{n}\right)
$$

Finally, controlling for $x_{n}$, there are also variations in $P_{j n}$ due to a third type of heterogeneity - namely differences in inventiveness between source countries. Inventiveness can refer to the overall quantity and/or quality of patentable inventions produced. Let $\iota_{j}$ be the level of inventiveness of the $j$-th source country. As a variant on Eaton and Kortum (1996), it is assumed that $\iota_{j}=\iota S_{j}^{\gamma} L_{j}^{1-\gamma}$, where $S$ denotes scientists and engineers, $L$ total labor, 
and $\gamma$ and $\iota$ are parameters. The idea is that 'inventiveness per worker' is related to the fraction of workers engaged in research and inventive activity (i.e. $S_{j} / L_{j}$ ). The $\iota_{j}$ variable is used to help control for differences in the quantity and quality of inventions between source countries. ${ }^{6}$

In particular, the source country's level of inventiveness is assumed to affect the total quantity of patentable inventions as well as the critical quality level. Hence:

$$
P_{j n}=Q_{j}\left(\iota_{j}\right)-q_{n}^{*}\left(x_{n}, \iota_{j}\right)=P_{j n}\left(x_{n}, \iota_{j}\right)
$$

where the greater the $\iota_{j}$, the greater the number of patentable inventions (i.e. $\partial Q_{j} / \partial \iota_{j}>0$ ) and/or the lower the critical 'cutoff' quality (i.e. $\partial q_{n}^{*} / \partial \iota_{j}<0$ ). In summary, patent flows from country $j$ to country $n$ have been derived as a function of both source and destination attributes.

\subsection{Total Factor Productivity}

Consider the following aggregate production function (which is a variant of that from Rivera-Batiz and Romer, 1991):

$$
Y=L^{1-\beta}\left(\int_{0}^{A} x_{i}^{\alpha} \mathrm{d} i\right)\left(\int_{0}^{A^{*}} x_{i^{*}}^{* \alpha^{*}} \mathrm{~d} i^{*}\right)
$$

where $Y$ denotes output, $L$ labor, $x$ domestic intermediate capital goods, $x^{*}$ imported intermediate capital goods, $A$ an index of the most recently invented domestic good, and $A^{*}$ an index of the most recently invented foreign good. The stock of national physical capital is:

$$
K=\left(\int_{0}^{A} x_{i} \mathrm{~d} i\right)\left(\int_{0}^{A^{*}} x_{i^{*}}^{*} \mathrm{~d} i^{*}\right)
$$

To simplify this further, assume $x_{i}=\bar{x}$ and $x_{i^{*}}^{*}=\bar{x}^{*}$ for all $i, i^{*}$ respectively (so that $K=A \bar{x}+A^{*} \bar{x}^{*}$ ). Let $\eta$ be the share of domestic intermediate capital goods in the stock of national capital; that is, $A \bar{x}=\eta K$ and $A^{*} \bar{x}^{*}=(1-\eta) K$. Substituting these relationships into equation (5) yields:

$$
Y=L^{1-\beta}\left(\Lambda K^{\alpha+\alpha^{*}} A^{1-\alpha} A^{* 1-\alpha^{*}}\right), \quad \text { where } \Lambda=\eta^{\alpha}(1-\eta)^{\alpha^{*}}>0 .
$$

6 Of course the productivity of scientists and engineers can vary across countries as well so that inventors in some country could produce more patent-worthy inventions than those in other countries (holding other factors constant). That kind of heterogeneity is more difficult to capture and is not attempted here. In the empirical section, this will affect only the pooled results and not the disaggregated source country results (since this kind of heterogeneity would not vary by destination countries). Other source country differences such as R\&D as a percentage of GDP were incorporated but were found to be statistically insignificant in explaining between-source country patenting behavior. 
Letting $\beta=\alpha+\alpha^{*}$ gives:

$$
Y=L^{1-\beta} K^{\beta}, \quad \text { where } T F P=\Lambda A^{1-\alpha} A^{* 1-\alpha^{*}} .
$$

Hence, TFP is a function of the stocks of both domestic knowledge $(A)$ and foreign knowledge $\left(A^{*}\right)$ :

$$
T F P=T F P\left(A, A^{*}\right)
$$

As discussed later, the stocks of domestic and foreign patents will be used as measures of $A$ and $A^{*}$ respectively. A rationale for this is that patents embody particular pieces of novel scientific and technological knowledge.7 Both equations (4) and (9) are the subject of the empirical analyses in sections 4-6.

\section{Data}

A panel data set of 25 source countries and 44 destination countries was assembled for 1975 - 2005 (every five years). The following describe the data used in this paper:

(i) International Patenting: International patenting data are from the World Intellectual Property Office (WIPO). The data indicate where patent applications come from and where they go. Some clarifications are in order here. A domestic patent application is a patent application made by a resident of the country. The resident need not be a national of that country, but say a subsidiary of a foreign multinational corporation that lists its address in that country. Likewise, a foreign patent application is an application by a non-resident, but this agent may be a national applying from an address listed abroad. These distinctions imply that stronger patent rights may attract patent applications from foreign nationals, but that the effect may show up not in foreign patent applications, but in domestic applications. Thus some care is needed when interpreting the data and results.$^{8}$

(ii) Patent Rights: The measure of patent rights is taken from Ginarte and Park (1997) and Park (2008). These studies provide an index of the strength - not necessarily quality - of patent rights across countries and over time. The index of patent rights (henceforth IPR) ranges from zero (weakest) to five (strongest). The value of the index is obtained by aggregating five sub-indices: extent of coverage, membership in international treaties, enforcement mechanisms, duration of protection, and provisions against loss

\footnotetext{
7 Note, however, the assumption in (9) that domestic and foreign patentable knowledge are not perfect substitutes. Patentees may have tailored inventions to national or local markets. There might also be important quality differences. Given the generally higher cost of filing patents abroad, patentees may file patents abroad only for inventions of rather high quality or high value.

8 In practice, however, most resident patent applications are by nationals; see Ham (1999).
} 
of protection (against, for example, compulsory licensing). These features (coverage, membership, duration, enforcement, and loss of protection) were chosen as a reference point because of their adoption in international standards, for example, the Trade-Related Intellectual Property Rights Agreement (TRIPS) of 1995.

The numerical value of each of these sub-indices (which range from zero to one) indicates the fraction of legal features in that sub-index available in the particular country. For example, a value of $1 / 3$ for enforcement indicates that a country has one-third of the possible enforcement mechanisms listed under that sub-index. A value of $1 / 2$ for duration implies that a country grants protection for half the international standard time (of 20 years from the date of application or 17 years from the date of grant). The value for membership in international treaties indicates the fraction of available treaties to which the nation is a signatory. The value for coverage indicates the fraction of invention classes the country allows as patentable subject matter. Finally, several conditions exist under which authorities can revoke or reduce patent rights. The value for provisions against loss of protection indicates the fraction of those conditions which are not exercised in the country.

(iii) Patent Filing Costs: Patent filing costs are the sum of: 1) official fees; 2) translation fees; and 3) agent (attorney) fees.9. Official filing fees were obtained from WIPO's PCT Applicant's Guide (current and back issues) and directly from national patent offices (for countries that are not members of the Patent Cooperation Treaty, PCT).

Agent and translation costs are generated from the Global IP Estimator. ${ }^{10}$ The costs are based on an application drafted in English, with ten claims, twenty pages of specification, and two sheets of drawing. ${ }^{11}$ The program generates costs in nominal U.S. dollars. The data are then adjusted here for two reasons: first, the data are available for a cross section of countries (not over time); secondly, the translation costs are from an English-speaking inventor's perspective; that is, while a U.S. patent applicant has no translation burden in the United Kingdom, a Danish applicant would.

To extrapolate translation costs for other source and destination country combinations, an equation is estimated that best fits the available translation cost data. The fitted equation is then used to predict translation costs for

9 There are other costs associated with procuring a patent such as 'search and examination' costs, notarization charges, and taxes. These are not included as they would not add much variability to the data across regions. Patent renewal fees (and enforcement costs) are also omitted since these are incurred after a patent is procured.

${ }^{10}$ This is a software program produced by Computer Software Associates (www.globalip.com). The program generates cost figures after the user inputs information about the page length of a patent application, the number of claims, sheets of drawings, the countries to which it will be filed, and so forth. The estimates are based on the minimum fees schedules supplied by associates in various countries.

${ }^{11}$ This patent model (10 claims, 20 pages, 2 drawings) has been used as a 'representative

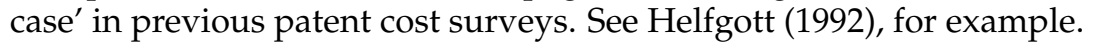


each and every pair of source and destination countries. The variable found that best instruments for translation costs is an index of language similarity. ${ }^{12}$ This index indicates the likelihood that two randomly selected persons from each country would speak the same language. Hence the greater the linguistic similarity between two countries, the lower should be the translation costs between them. Indeed, the following fitted equation bears this out:

$$
\log (\text { TRAN̂S }+1)=6.71-0.56 \cdot \log (\text { LING }+1)
$$

$$
\text { (0.67) (0.13) }
$$

where $A d j-R^{2}=0.31$, and the number of observation is 44 . TRANS denotes translation costs and $L I N G$ the linguistic similarity index (the 'ones' being added since the variables can taken on zero values). The regression was run with U.S. data; specifically, translation costs for U.S. applications in 44 destinations were regressed on the linguistic similarity between the U.S. and those 44 countries. As predicted, the latter has a significant negative effect on the former. Heteroskedastic-consistent standard errors are in parentheses. With equation (10) and data on the RHS variable, the cost of translating a patent from any source country in any destination country can be generated. To maintain consistency (in the way translation costs are measured), the original data are replaced with the fitted data.

(iv) Market Size and Capacity for Imitation: Market size is measured by GDP (in real 1985 PPP adjusted U.S. dollars) ${ }^{13}$ rather than GDP per capita (or per worker), since the latter may pick up information on labor costs or productivity.

The capacity to imitate is given by a weighted average of two characteristics that the literature identifies as important indicators of the technological capacity of a country; namely, scientists and engineers per 10,000 workers (S\&E) and research and development as a share of GDP (RDY). Both could reflect innovative capacity as well as imitative capacity. The two are not mutually exclusive: patentees may perceive the hazard of imitation to be high in places where innovative capacity is high. The index of imitative capacity is given by:

$$
I M I T=\theta_{s}(S \& E)+\theta_{r}(R D Y)
$$

where $\theta_{s}+\theta_{r}=1$ and $\theta_{s}=\frac{\operatorname{var}(S \& E)^{-1}}{\operatorname{var}(S \& E)^{-1}+\operatorname{var}(R D Y)^{-1}}<1$. That is, the weights are based on the relative precisions (or inverse of the variances) of S\&E and RDY over the sample period.

(v) TFP and Physical Capital: The log of total factor productivity is given by:

$$
\log T F P=\log Y / L-\beta \log K / L
$$

\footnotetext{
12 Data on linguistic similarity are from Boisso and Ferrantino (1996).

13 The GDP data are for from the Penn World Tables.
} 
where $Y$ is GDP, $K$ physical capital, and $L$ labor. It is assumed that $\beta=0.3$. Data on GDP per worker and physical capital per worker are from the Penn World Tables. For those missing data, the perpetual inventory method is used to obtain stock data using gross investment flows (as shown in a Web Appendix).

(vi) Knowledge Capital Stocks: Data on knowledge capital are also derived using the perpetual inventory method. As shown in the appendix:

$$
\begin{gathered}
A(t)=P(t-5)+(1-\delta) A(t-1) \\
A^{*}(t)=P^{*}(t-5)+(1-\delta) A^{*}(t-1)
\end{gathered}
$$

where $A\left(A^{*}\right)$ denotes the stock of domestic (foreign) patentable knowledge and $P\left(P^{*}\right)$ the flow of domestic (foreign) patents. Note that $P^{*}=\sum P_{i}^{*}$, where $i$ denotes the $i$-th foreign (source) country. The paper assumes that flows of patents affect the stock of knowledge with a lag of 5 years and that the depreciation rate, $\delta$, is $10 \%$. A Web Appendix reports on the sensitivity of the main results to these assumptions (and also describes how initial patent knowledge stocks are derived).

\section{Empirical Results: Determinants of Internatio- nal Patenting}

This section focuses on estimating the international patenting equation. First, Table 1 provides some sample statistics. The countries in the sample are grouped according to their sample average real GDP per capita. In general, the high-income nations do the most domestic patenting, receive the most patents from abroad, and patent abroad the most. The cost of patenting is generally highest in the high-income region, where patenting activity (and pressure on patenting resources) is greatest. While official fees (for filing patents) are not particularly high in developing countries, the supply of patent agents is relatively scarce, making lower-income nations relatively expensive (compared to their market size). The high-income nations also have overall the highest levels of IPR, market freedom, and innovative and imitative capacity, as indicated by the ratios of R\&D to GDP and of scientists and engineers to the total workforce. The market freedom index is included as a proxy for the level of property rights in general.

Table 1 also provides some sample correlations. A high degree of correlation exists between domestic patents and patents abroad (since the more inventions a country has, the more it can file abroad). Patenting activity is also positively correlated with R\&D to GDP and S\&E to workers. IPR is positively correlated with the more general measure of property rights (i.e. MKT) and with the R\&D to GDP ratio and GDP per capita.

The international patenting model is first estimated for the case where all the source countries are pooled. Simplifying equation (4) as a log linear 
Table 1 - Sample Statistics (Average 1975-2005)

\begin{tabular}{|c|c|c|c|c|c|c|c|c|c|c|}
\hline \multirow{2}{*}{\multicolumn{2}{|c|}{$\begin{array}{l}\text { Income } \\
\text { Group }\end{array}$}} & \multirow[b]{2}{*}{ GDPC } & \multirow[b]{2}{*}{ PCOST } & \multirow[b]{2}{*}{ IPR } & \multirow[b]{2}{*}{ MKT } & \multirow{2}{*}{$\begin{array}{r}\text { R\&D/ } \\
\text { GDP }\end{array}$} & \multirow{2}{*}{$\begin{array}{r}\text { S\&E/ } \\
\text { Worker }\end{array}$} & \multirow{2}{*}{$\begin{array}{r}\text { Domestic } \\
\text { Patents }\end{array}$} & \multirow{2}{*}{$\begin{array}{l}\text { Foreign } \\
\text { Patents }\end{array}$} & \multirow{2}{*}{$\begin{array}{l}\text { Patents } \\
\text { Abroad }\end{array}$} \\
\hline & & & & & & & & & & \\
\hline \multirow[t]{2}{*}{ High: } & Mean & 13166 & 2291 & 3,70 & 6,63 & 1,97 & 48,0 & 13586 & 35625 & 44965 \\
\hline & Std Dev & 1706 & 619 & 0,42 & 0,93 & 0,71 & 14,6 & 22057 & 17681 & 68496 \\
\hline \multirow[t]{2}{*}{ Medium: } & Mean & 5554 & 1148 & 2,54 & 5,02 & 0,67 & 19,5 & 2090 & 9699 & 1702 \\
\hline & Std Dev & 1923 & 745 & 0,74 & 0,96 & 0,55 & 29,1 & 5026 & 10315 & 1566 \\
\hline \multirow[t]{2}{*}{ Low: } & Mean & 1555 & 1439 & 2,38 & 4,41 & 0,28 & 5,5 & 178 & 2354 & 350 \\
\hline & Std Dev & 765 & 670 & 0,74 & 0,63 & 0,27 & 5,7 & 384 & 2419 & 226 \\
\hline \multirow[t]{2}{*}{ Overall: } & Mean & 8099 & 1732 & 2,97 & 5,62 & 1,16 & 29,1 & 6661 & 19389 & 31061 \\
\hline & Std Dev & 4921 & 830 & 0,88 & 1,24 & 0,92 & 26,3 & 15757 & 19473 & 59636 \\
\hline \multicolumn{2}{|c|}{ Correlation } & & & & & R\&D/ & S\&E/ & Domestic & Foreign & Patents \\
\hline \multicolumn{2}{|l|}{ Matrix: } & GDPC & PCOST & IPR & MKT & GDP & Worker & Patents & Patents & Abroad \\
\hline \multicolumn{2}{|l|}{ GDPC } & 1 & & & & & & & & \\
\hline \multicolumn{2}{|l|}{ PCOST } & 0,59 & 1 & & & & & & & \\
\hline \multicolumn{2}{|l|}{ IPR } & 0,72 & 0,67 & 1 & & & & & & \\
\hline \multicolumn{2}{|l|}{ MKT } & 0,76 & 0,53 & 0,56 & 1 & & & & & \\
\hline \multicolumn{2}{|l|}{$R \& D / G D P$} & 0,69 & 0,58 & 0,73 & 0,59 & 1 & & & & \\
\hline \multicolumn{2}{|c|}{ S\&E/Worker } & 0,57 & 0,36 & 0,57 & 0,29 & 0,71 & 1 & & & \\
\hline \multicolumn{2}{|c|}{ Domestic Patents } & 0,39 & 0,23 & 0,42 & 0,47 & 0,55 & 0,39 & 1 & & \\
\hline \multicolumn{2}{|c|}{ Foreign Patents } & 0,63 & 0,47 & 0,64 & 0,62 & 0,65 & 0,25 & 0,69 & 1 & \\
\hline \multicolumn{2}{|c|}{ Patents Abroad } & 0,46 & 0,25 & 0,46 & 0,49 & 0,58 & 0,39 & 0,97 & 0,73 & 1 \\
\hline
\end{tabular}

Notes: GDPC - GDP per capita in real 2000 PPP U.S. dollars (Source: World Bank "World Development Indicators")

PCOST - Patent Filing Costs in real 2000 U.S. dollars (Source: Based on Global IP Estimator and WIPO "PCT Applicant's Guide")

IPR - Index of Patent Rights (Source: Ginarte and Park (1997) and Park (2008))

MKT - Index of Market Freedom (Source: Gwartney and Lawson (2009))

RD/GDP - Research and Development as a \% of GDP (Source: UNESCO)

SE/Worker - Number of Scientists and Engineers per 10,000 Workers (Source: UNESCO)

DOMESTIC PATENTS - Total Patents filed by residents (Source: WIPO "Industrial Property Statistics")

FOREIGN PATENTS - Total Patents filed by nonresidents (Source: WIPO "Industrial Property Statistics")

PATENTS ABROAD - Total Patents filed abroad by residents (Source: WIPO "Industrial Property Statistics")

function (i.e. $\log P_{j n}=\mu+\log \iota_{j}+\log x_{n}+\epsilon$, where $\mu$ is a constant and $\epsilon$ a stochastic error term), and utilizing the time subscript $t$ yields:

$$
\log \left(P_{j n t} / L_{j t}\right)=\rho_{0}+\log x_{n t}+\gamma \log \left(S_{j t} / L_{j t}\right)+\epsilon_{n t}
$$

where $\rho_{0}=\mu+\log \iota$ and where $\iota_{j}=\iota S_{j}^{\gamma} L_{j}^{1-\gamma}$ has been incorporated. The variable $x_{n t}$ itself is a function of destination country attributes (e.g. market size, IPR level, imitative capacity, and patenting cost):

$$
x_{n t}=\rho_{1} \log G D P_{n t}+\rho_{2} \log I P R_{n t}+\rho_{3} \log I M I T_{n t}+\rho_{4} \log P C O S T_{n t}
$$

where $\rho_{1}, \ldots, \rho_{4}$ are coefficients. The dependent variable in (11) is the bilateral patent flow (from source to destination) per source country labor, and $S_{j t} / L_{j t}$ the source country's ratio of scientists and engineers to workers. The error term $\epsilon_{n t}$ is motivated by the fact that some profitable inventions fail to be patented, while some unprofitable ones are patented. The possibility of random or fixed destination effects is also considered.

The first three columns of Table 2 provide the OLS, fixed effects (FE), and random effects (RE) estimates of equation (11). The model is estimated 
Table 2 - Patent Filings - Aggregate Estimates

\begin{tabular}{|c|c|c|c|c|c|}
\hline & \multicolumn{5}{|c|}{ Dependent Variable: log (PATENTS/LABOR) } \\
\hline & (1) & (2) & (3) & (4) & (5) \\
\hline & $\underline{\mathrm{OLS}}$ & $\underline{\mathrm{FE}}$ & $\underline{\mathrm{RE}}$ & $\underline{\mathrm{FE}}$ & $\underline{\mathrm{FE}}$ \\
\hline Constant & $\begin{array}{l}-19.9 \\
(0.47)\end{array}$ & -- & $\begin{array}{l}-15.92 \\
(0.661)\end{array}$ & -- & -- \\
\hline $\log$ GDP & $\begin{array}{l}0.585 \\
(0.021)\end{array}$ & $\begin{array}{l}1.579 \\
(0.101)\end{array}$ & $\begin{array}{l}0.635 \\
(0.032)\end{array}$ & $\begin{array}{l}0.972 \\
(0.105)\end{array}$ & $\begin{array}{l}1.536 \\
(0.101)\end{array}$ \\
\hline $\log I P R$ & $\begin{array}{l}2.267 \\
(0.093)\end{array}$ & $\begin{array}{l}2.403 \\
(0.143)\end{array}$ & $\begin{array}{l}2.208 \\
(0.099)\end{array}$ & $\begin{array}{l}1.904 \\
(0.135)\end{array}$ & $\begin{array}{l}3.594 \\
(0.167)\end{array}$ \\
\hline log IMIT & $\begin{array}{l}0.592 \\
(0.036)\end{array}$ & $\begin{array}{l}0.965 \\
(0.079)\end{array}$ & $\begin{array}{l}0.826 \\
(0.041)\end{array}$ & $\begin{array}{l}0.771 \\
(0.084)\end{array}$ & $\begin{array}{l}-0.160 \\
(0.128)\end{array}$ \\
\hline log PCOST & $\begin{array}{l}-0.673 \\
(0.039)\end{array}$ & $\begin{array}{l}-1.946 \\
(0.077)\end{array}$ & $\begin{array}{l}-1.232 \\
(0.046)\end{array}$ & $\begin{array}{l}-2.031 \\
(0.076)\end{array}$ & $\begin{array}{l}-1.829 \\
(0.079)\end{array}$ \\
\hline log S\&E & $\begin{array}{l}1.828 \\
(0.033)\end{array}$ & $\begin{array}{l}0.934 \\
(0.066)\end{array}$ & $\begin{array}{l}1.611 \\
(0.038)\end{array}$ & $\begin{array}{l}0.769 \\
(0.065)\end{array}$ & $\begin{array}{l}0.893 \\
(0.066)\end{array}$ \\
\hline $\log$ MKT & -- & -- & -- & $\begin{array}{l}1.221 \\
(0.092)\end{array}$ & -- \\
\hline $\log I P R^{*} \log I M I T$ & -- & -- & -- & -- & $\begin{array}{l}1.091 \\
(0.099)\end{array}$ \\
\hline Adjusted $\mathrm{R}^{2}$ & 0.673 & 0.905 & 0.646 & 0.911 & 0.908 \\
\hline $\begin{array}{l}\text { F-Test } \\
\chi^{2} \text {-test }\end{array}$ & 10.79 & & 328.26 & & \\
\hline
\end{tabular}

Notes: The dependent variable is the log of the number of patent filings (from the source country to the destination country) per (source-country) worker. Sample Size $=7700$ (where $T=7$ time periods and $N=1100$ bilateral pairs (i.e. 25 source countries $\times 44$ destination countries)). FE, RE denote fixed and random effects estimates respectively. IMIT is an index of the imitation capacity of the destination country, derived as a weighted average of the ratio of RD to GDP and the number of scientists and engineers per 10,000 workers, where the weights are given by the relative precision (i.e. inverse of the variance) of each variable during the sample period. SE denotes the source country's number of scientists and engineers per 10,000 workers. See Table 1 for other variable definitions. Heteroskedastic-consistent standard errors are in parentheses. F-test is the statistic for testing the null of common intercepts (or of no individual effects) and $\chi^{2}$-test the statistic for testing the null of no correlation between the individual effects and other regressors. 
for the pooled sample of 25 source countries, each of which faces 44 destination countries (including itself) over 1975 - 2005. The RHS variables all have the expected sign and are significant at conventional levels. An F-test, however, suggests the presence of individual (destination) effects and the $\chi^{2}$-test suggests correlation between these effects and the RHS variables hence the focus will be on the fixed effects results. Column (2) indicates that the response of patent filings to the level of patent rights is quite elastic. A $1 \%$ increase in IPR raises patent filings by more than $1 \%$. It may be tempting to interpret this as a kind of 'increasing return'; however, determining the return to investing in the patent system would require some information on the costs to the economy of strengthening patent rights by a certain level (say resource costs) and the value of those additional patent filings. The demand for patenting is also price-elastic (as shown by the coefficient of PCOST). This finding has some policy relevance to the setting of patent office fees. The results also show that source countries with a higher ratio of scientists and engineers to workers (S\&E) tend to patent more and that destination countries with a higher level of imitative capacity (IMIT) and larger market size (GDP) tend to attract more patents, holding other factors constant.

One issue though is whether the IPR variable is picking up property rights protection in general. As column (4) shows, the inclusion of the market freedom variable (MKT) reduces the quantitative effect of IPR, but the variable remains quite significant. Thus patent rights protection has an independent effect above and beyond general property rights protection. Another issue is whether IPRs might also have an interactive effect with some other variable. For example, Smith (1999) suggests that strong patent rights may matter less in nations with weak imitative abilities to begin with. In column (5), the inclusion of an interaction variable, i.e. $\log (\mathrm{IPR})^{*} \log (\mathrm{IMIT})$, shows that patent rights do more to stimulate patenting in countries that are more capable of imitating. However, the IMIT variable alone becomes statistically insignificant in determining patenting; imitative capacity influences patenting through the interaction term only. The reason is that in nations with greater imitative capabilities, the threat of imitation increases the demand for patents only if patent rights are strong; otherwise applying for a patent is a poor way to protect against imitation.

\section{Empirical Results: Effects on Total Factor Pro- ductivity}

From equations (8) and (9), the log of TFP can be expressed as:

$$
\log T F P_{n t}=\varphi_{0}+\varphi_{1} \log A_{n t}+\varphi_{2} \log A_{n t}^{*}+\xi_{n t}
$$

where $\varphi_{0}=\log \Lambda, \varphi_{1}=(1-\alpha)$, and $\varphi_{2}=\left(1-\alpha^{*}\right)$. Note that subscripts for time $t$ and country $n$ are included, as well as a log additive error term $\xi_{n t}$. 
As emphasized earlier, the stocks of knowledge are proxied by the stocks of patentable knowledge. Of course, not all knowledge is patented (that is, some may be kept as trade secrets) or patentable (e.g. mathematical and organizational knowledge, or restricted fields like genetic engineering). On the other hand, some ideas that are patented have little or no commercial value. These are factors to consider when interpreting the empirical results.

\section{Table 3 - Total Factor Productivity and Stocks of Patents}

\begin{tabular}{|c|c|c|c|c|}
\hline \multicolumn{5}{|c|}{ Dependent Variable: $\log (T F P)=[\log$ GDP per worker $-0.3 \log$ Capital per worker $]$} \\
\hline & $\underline{\mathrm{FE}}$ & $\underline{\mathrm{RE}}$ & $\underline{\mathrm{FE}}$ & $\underline{\mathrm{RE}}$ \\
\hline Constant & -- & $\begin{array}{l}5.066 \\
(0.13)\end{array}$ & -- & $\begin{array}{l}5.431 \\
(0.153)\end{array}$ \\
\hline log DOMESTIC & $\begin{array}{l}0.110 \\
(0.024)\end{array}$ & $\begin{array}{l}0.100 \\
(0.016)\end{array}$ & $\begin{array}{l}0.091 \\
(0.026)\end{array}$ & $\begin{array}{l}0.065 \\
(0.015)\end{array}$ \\
\hline log FOREIGN & $\begin{array}{l}0.077 \\
(0.015)\end{array}$ & $\begin{array}{l}0.078 \\
(0.013)\end{array}$ & $\begin{array}{l}0.056 \\
(0.015)\end{array}$ & $\begin{array}{l}0.046 \\
(0.014)\end{array}$ \\
\hline $\log (I P R)$ & -- & -- & $\begin{array}{l}-0.070 \\
(0.071)\end{array}$ & $\begin{array}{l}-0.059 \\
(0.045)\end{array}$ \\
\hline $\log (R \& D / G D P)$ & -- & -- & $\begin{array}{l}0.036 \\
(0.035)\end{array}$ & $\begin{array}{l}0.043 \\
(0.022)\end{array}$ \\
\hline $\log (S \& E / L A B O R)$ & -- & -- & $\begin{array}{l}0.061 \\
(0.025)\end{array}$ & $\begin{array}{l}0.106 \\
(0.023)\end{array}$ \\
\hline Adj $R^{2}$ & 0.93 & 0.56 & 0.94 & 0.69 \\
\hline F-Test & 77.5 & -- & 43.4 & -- \\
\hline \multirow[t]{2}{*}{$\begin{array}{l}\chi^{2} \text {-Test } \\
\text { (p-value) }\end{array}$} & -- & $\begin{array}{l}0.3003 \\
(0.861)\end{array}$ & -- & $\begin{array}{l}21.3 \\
(0.0007)\end{array}$ \\
\hline & Mean & Std Dev. & Min & Max \\
\hline TFP & 872 & 371 & 185 & 1627 \\
\hline CAPITAL per worker & 21781 & 16466 & 428 & 83744 \\
\hline DOMESTIC & 38610 & 100508 & 4.8 & 683612 \\
\hline FOREIGN & 68590 & 101067 & 79 & 528023 \\
\hline
\end{tabular}

Notes: The number of observations is 308 (=44 countries $\times 7$ years). DOMESTIC denotes the stock of domestic patentable knowledge and FOREIGN the stock of foreign patentable knowledge. TFP and Capital per worker are in real 2000 U.S. PPP dollars, while the stocks of patents are quantities ('counts'). The F- and $\chi^{2}$-test statistics are as defined in Table 2. Heteroskedastic-consistent standard errors are in parentheses

Table 3 presents the results of estimating equation (12) and some additional sample statistics. There is greater variation in domestic and foreign patent knowledge capital than there is in TFP and capital per worker (as would be seen from computing the coefficients of variation). The first two columns of Table 3 report the fixed and random effects estimates of equation (12). In the table, DOMESTIC refers to $A$ and FOREIGN to $A^{*}$. The F-test indicates the presence of individual country effects and the $\chi^{2}$-test indicates no significant correlation between the individual effects and the regressors; 
hence the focus will be on the random effects estimates. In any case, the coefficient estimates (between the two estimators) are similar: domestic patent knowledge has a TFP-elasticity of 0.1 while foreign patent knowledge has a TFP elasticity just under 0.08. Coupled with the fact that the mean stock of domestic patent knowledge is 1.77 times smaller than the mean stock of foreign patent knowledge, the estimates suggest that a unit change in domestic knowledge capital has the slightly greater effect on TFP. Thus while foreign patents may generally be of higher quality, this might be outweighed by the fact that domestic patents serve more local needs. Overall, the random effects model explains $56 \%$ of the variation in TFP.

Two important assumptions underlie the construction of the patent knowledge stocks: first, an assumption about the depreciation rate (that is, the rate at which patentable knowledge becomes obsolete), and secondly an assumption about the lag length between gross patent flows and their effects on the stock of patentable knowledge (that is, it takes time for patent applications to become part of the stock of knowledge, time for instance to search and examine applications for patentability, to further develop the invention, and to be disclosed publicly). Thus far, a geometric depreciation rate of $10 \%$ and lag length of five years have been assumed. The Web Appendix shows that the results are not particularly sensitive to these assumptions.

Lastly, columns three and four of Table 3 report the results of including other variables: IPR, the ratio of R\&D to GDP, and the ratio of scientists and engineers to workers. The results show that both domestic and foreign patent knowledge capital remain strongly significant determinants of TFP (although their quantitative effects are reduced somewhat). Interestingly, patent rights do not have a statistically significant direct effect on TFP. Only the scientists and engineers variable has a significant direct effect on TFP above and beyond its indirect effect through patenting. R\&D has a direct significant effect in the random effects model but not in the fixed effects model. The random effects model, however, fails the Hausman specification test (see the $\chi^{2}$-test). The additional regressors are correlated with the country-specific effects.

\section{Simulations: Effects on Technological Gap}

The results from the previous two sections are combined here to determine how international patent reform would affect international technology diffusion and technology gaps. Essentially the simulations involve certain countries raising their IPR level by a certain amount. By equation (11), this stimulates patenting in those countries. Both domestic patenting and patenting by foreigners increase by a certain amount. The increases in domestic and foreign patenting in turn feed into the stocks of domestic and foreign patentable knowledge. Then by equation (12), the increased stocks 
of patentable knowledge stimulate domestic TFP. The experiments compare the distribution of TFP among countries before and after the change in patent rights so as to assess (i) how significantly international patent reform would raise the mean TFP, and (ii) whether this kind of reform would narrow or widen global technology gaps. The latter issue is assessed by examining the standard deviation and skewness of TFP across countries. The simulations, however, are short run (looking at the one period ahead effects, where each period occurs at five year intervals).

These simulations have implications for how and what developing nations would gain from strengthening their patent regimes. Would their reforms sufficiently stimulate domestic and foreign patenting, and would these outcomes enhance their ability to catch up? What has not yet been investigated in the existing literature, however, is who would gain relatively most: the less developed or more developed economies? A uniform worldwide strengthening of IPRs would presumably stimulate patenting worldwide. If poorer economies gain relatively more patentable knowledge than the richer gain, the technology gap could be narrowed; otherwise it could widen. It might be necessary to concentrate patent reform in certain regions (for example, the developing world) and to distribute the burden of reform unevenly (for example, poorer economies would undergo larger regime shifts). Thus it is not yet clear how international patent reform would affect the relative standing between developed and developing nations.

First, some details about the experimental setting. As benchmark values, the sample averages are used; that is, all the relevant variables have been averaged over the sample period (to smooth out short run fluctuations). In the base case scenario, there are no changes in national IPRs.

In the first simulation (Case 1), all destination countries raise their IPR by 0.44 points, which equals half the sample standard deviation of IPR (see Table 1). Of course, this is relatively a small percentage change in IPR for strong patent destinations and a large one for weak patent destinations. In each destination, the higher IPR attracts patents from the various source countries. From equation (11), the increase in patents from the $j$-th source country to the $n$-th destination country is:

$$
\Delta P_{j n}=\lambda P_{j n}
$$

where $\lambda=\left[\rho_{j 2}+\rho_{j 5} \log I M I T_{n}\right]\left[\% \Delta I P R_{n}\right] / 100 . \rho_{j 2}$ is the coefficient estimate of $\log$ IPR and $\rho_{j 5}$ the coefficient estimate of the interaction term (log IPR * $\log$ IMIT) for the $j$-th source country. ${ }^{14}$ In (13), $\lambda$ is the rate of increase in patents from country $j$ to country $n$ and $P_{j n}$ the previous level of patents from $j$ to $n$ (again, $j=n$ refers to domestic patenting.) The growth rate of patents, $\lambda$, equals the percentage change in country $j$ 's patenting in destina-

14 The model in column 5 of Table 2 was estimated for each country separately, and the coefficient estimates from these separate country regressions were used as values for $\rho_{j 2}$ and $\rho_{j 5}$ in equation (13). 
tion $\mathrm{n}$ per $1 \%$ change in $n^{\prime}$ s IPR level times the total percentage change in destination $n$ 's IPR level.

Given the new flows of domestic and foreign patents, the effect on TFP can be estimated. For the nth destination country, the new stocks of domestic and foreign patentable knowledge are:

$$
\begin{aligned}
A_{n}^{\prime} & =P_{n n}+(1-\delta) A_{n} \\
A_{n}^{* \prime} & =\left(\sum_{j \neq n} P_{j n}\right)+(1-\delta) A_{n}^{*}
\end{aligned}
$$

where the $P_{n n}$ 's and $P_{j n}$ 's are the new flows. Recall that the $P^{\prime}$ s are lagged five years vis-a-vis $A, A^{*}$ (or rather in this simulation, the $A, A^{*}$ and TFP lead the $P^{\prime}$ s and IPR changes by five years) 15 By equation (12), the increased stocks of $A_{n}, A_{n}^{*}$ in turn raise $\mathrm{TFP}_{n}$. The coefficient estimates in column 2 of Table 3 are used in predicting the new total factor productivities.

Table 4 provides some summary statistics of the simulations. In the first simulation (Case 1), the mean IPR is 3.41, compared to 2.97 in the base case scenario. The standard deviation of IPR remains the same since all countries have raised their IPR by 0.44 points. Mean TFP rises from $\$ 893$ to $\$ 906$ (in real 1985 U.S. PPP dollars) but the coefficient of variation in TFP is slightly higher. This is because both developed and developing nations experience increases in TFP due to the uniform worldwide increase in IPR levels, so that the spread in TFP across countries in fact widens. The distribution of TFP is also slightly more negatively skewed; that is, the weight is slightly more concentrated at the "upper end". 16

On the other hand, the mean share of the world patent stock is slightly higher. This statistic is a country's total patent stock (i.e. domestic plus foreign) as a percentage of the world stock of patents. The world stock of patents in turn is just the sum of all domestic patent stocks. Under Case 1, the average country has $6.75 \%$ of the world's stock of patentable knowledge (up from $6.57 \%$ under the base case scenario). The coefficient of variation of the world patent stock is lower (from 1.64 to 1.60), and less positively skewed; that is, the weight is less concentrated at the lower end of the distribution. The strengthening of IPRs enables more countries to get access to existing patentable knowledge. Another perspective is provided by the share of world patent stock, not counting domestic patents. This statistic is a country's foreign patent stock as a percentage of the rest of the world's

\footnotetext{
${ }^{15}$ Note that for the non-source countries, the average coefficient (of log IPR and of $\log$ $I P R^{*} \log$ ) of the 25 source countries is used to approximate the effects of IPR changes in non-source countries on their own domestic patenting. The simulation also assumes that the foreign patenting of these non-source countries is negligible, which is reasonable, even in the case of Korea, which did not patent heavily abroad prior to the 1990s. If it were not neglected, it would only support the finding below that the developed economies gain relatively more patents vis-a-vis the developing economies under certain kinds of reform.

${ }^{16}$ Here SKEW $=($ MEAN - MEDIAN $) / \sigma$, where $\sigma=$ Standard Deviation.
} 
Table 4 - Simulation Results: Distribution of TFP and World Patent Stock

\begin{tabular}{|c|c|c|c|c|}
\hline Base Case Scenario & $\underline{\text { IPR }}$ & $\begin{array}{l}\text { Predicted } \\
\underline{\text { TFP }}\end{array}$ & $\begin{array}{l}\% \text { Share } \\
\text { of World } \\
\text { Patent Stock }\end{array}$ & $\begin{array}{l}\text { \% Share of World } \\
\text { Patent Stock } \\
\text { (excluding Domestic) }\end{array}$ \\
\hline Mean & 2.97 & $\overline{893}$ & 6.57 & 4.76 \\
\hline Std Dev & 0.88 & 369.1 & 10.8 & 6.92 \\
\hline Skew & -0.27 & -0.24 & 2.97 & 2.36 \\
\hline $\begin{array}{l}\text { Coefficient } \\
\text { of Variation }\end{array}$ & 0.29 & 0.413 & 1.64 & 1.45 \\
\hline Case 1: & $\underline{\text { IPR }}$ & $\begin{array}{l}\text { Predicted } \\
\underline{\text { TFP }}\end{array}$ & $\begin{array}{l}\% \text { Share } \\
\text { of World } \\
\text { Patent Stock }\end{array}$ & $\begin{array}{l}\text { \% Share of World } \\
\text { Patent Stock } \\
\text { (excluding Domestic) }\end{array}$ \\
\hline Mean & 3.41 & $\overline{906}$ & 6.75 & 4.94 \\
\hline Std Dev & 0.88 & 374.7 & 10.8 & 6.96 \\
\hline Skew & -0.27 & -0.25 & 2.90 & 2.26 \\
\hline $\begin{array}{l}\text { Coefficient } \\
\text { of Variation }\end{array}$ & 0.25 & 0.414 & 1.60 & 1.41 \\
\hline Case 2: & $\underline{\text { IPR }}$ & $\begin{array}{l}\text { Predicted } \\
\underline{\text { TFP }}\end{array}$ & $\begin{array}{l}\% \text { Share } \\
\text { of World } \\
\text { Patent Stock }\end{array}$ & $\begin{array}{l}\text { \% Share of World } \\
\text { Patent Stock } \\
\text { (excluding Domestic) }\end{array}$ \\
\hline Mean & 3.55 & 907 & 6.73 & 4.91 \\
\hline Std Dev & 0.68 & 369.6 & 10.7 & 6.79 \\
\hline Skew & -0.23 & -0.28 & 2.93 & 2.30 \\
\hline $\begin{array}{l}\text { Coefficient } \\
\text { of Variation }\end{array}$ & 0.19 & 0.407 & 1.58 & 1.38 \\
\hline Case 3: & $\underline{\text { IPR }}$ & $\begin{array}{l}\text { Predicted } \\
\underline{\text { TFP }}\end{array}$ & $\begin{array}{l}\% \text { Share } \\
\text { of World } \\
\text { Patent Stock }\end{array}$ & $\begin{array}{l}\text { \% Share of World } \\
\text { Patent Stock } \\
\text { (excluding Domestic) }\end{array}$ \\
\hline Mean & 3.69 & $\overline{907}$ & 6.71 & 4.88 \\
\hline Std Dev & 0.62 & 364.7 & 10.5 & 6.63 \\
\hline Skew & 0.28 & -0.30 & 2.96 & 2.33 \\
\hline $\begin{array}{l}\text { Coefficient } \\
\text { of Variation }\end{array}$ & 0.17 & 0.402 & 1.56 & 1.36 \\
\hline
\end{tabular}

Simulation Assumptions:

Base Case - No Change in IPR

Case 1 - All Countries increase their IPR by 0.44 points (= $1 / 2$ Sample Standard Deviation of IPR).

Case 2 - OECD Countries increase their IPR by 0.22 points,

Non-OECD Countries (plus Greece, Portugal, \& Turkey) increase their IPR by 0.88 points.

Case 3 - No Change in OECD IPR,

Non-OECD Countries (plus Greece, Portugal, \& Turkey) increase their IPR by 1.32 points.

Definitions:

$\%$ Share of World Patent Stock $=$ (Total Stock of Domestic and Foreign patents) $\times 100$ World Patent Stock

$\%$ Share of World Patent Stock = (Excluding domestic)

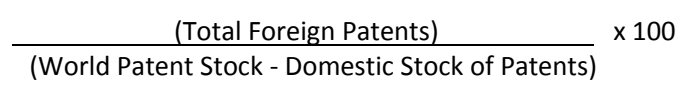

where World Patent Stock $=$ Sum of all Domestic Patent Stocks

Note: Base Case data are "averages" over the sample period (1975-2005).

patent stock. The latter is just the sum of the rest of the world's domestic patent stocks. This statistic helps focus on a nation's take of available foreign patent knowledge. Compared to the distribution of world patent stock, the mean share of the world patent stock excluding domestic patent stock is lower 
and its distribution more even and less positively skewed.

In the second simulation (Case 2), patent reform is asymmetric: OECD countries each increase their IPR level by 0.22 points, while non-OECD countries each increase theirs by $0.88 \cdot{ }^{17}$ The aim is to see whether a bigger patent reform by follower countries would do more to narrow the global spread in TFP. It turns out that the mean of TFP is just marginally higher than it was under Case 1 and its coefficient of variation marginally lower. The mean share of the world patent stock (including or excluding domestic patent stock) is actually lower, and more positively skewed (i.e. more concentrated at the lower end of the distribution). In fact, it is not the case that the patent reforms do not go far enough. In the third and last simulation (Case 3), OECD countries make no changes in their IPR while non-OECD countries each raise their IPR by 1.32 points. Even under this heavily asymmetric patent reform, the mean TFP and distribution of TFP do not change by much. The distribution of TFP becomes more negatively skewed (concentrated at the upper end). The mean share of the world patent stock is lower and its distribution further concentrated at the lower end.

The reason the mean TFP does not increase by much under Cases 2 and 3 is that the OECD economies are not stimulating their patenting activity and TFP as much as they did under Case 1, and are thus not pulling up the average. The coefficient of variation in TFP is reduced very marginally (considering how much effort it might take to strengthen IPR levels by 0.88 or 1.32 points). The reason is that patent knowledge stocks actually have a small measured impact on TFP. (As mentioned earlier, their coefficient estimates are small. Reasons for this will be elaborated shortly.) Thus, increases in patent knowledge stocks due to (even large) reforms in the patent system translate into small increases in TFP. Coupled with the fact that the TFP levels of the OECD economies are already much higher than those of the non-OECD, the small gains in TFP by non-OECD nations are not sufficient to close any technology gaps between them and the OECD.

The reason the mean share of the world patent knowledge stock falls under Cases 2 and 3 is that even within the OECD there are large differences in world patent knowledge shares between the major patenting nations (U.S., Japan, Germany, U.K., and France) and the rest of the OECD, and when the latter countries forgo strengthening their patent regimes, they also forgo increasing their share of the world patent knowledge stock. Hence the mean share falls, and the distribution of the world patent stock is more positively skewed. Overall, however, compared to the base case scenario, the mean share of the world patent stock is higher and its distribution less skewed.

Table 5 provides a detailed look at how much technological catch-up oc-

\footnotetext{
${ }^{17}$ Although Greece, Portugal and Turkey are members of the OECD, they are included in the non-OECD group because of both their relatively low per capita GDP and low IPR. The reason for performing different policies for the OECD and non-OECD is that most of the OECD economies have relatively high incomes and high IPRs.
} 
Table 5 - Simulation Results: Ranking of TFP and National Patent Stock

\begin{tabular}{|c|c|c|c|c|c|c|c|c|c|}
\hline & & \multicolumn{4}{|c|}{ TFP Relative to the U.S. } & \multicolumn{4}{|c|}{$\begin{array}{l}\text { Total Patent Stock Relative to the U.S. } \\
\text { Base }\end{array}$} \\
\hline & & Case & Case 1 & Case 2 & Case 3 & Case & Case 1 & Case 2 & Case 3 \\
\hline & Austral & 0,818 & 0,819 & 0,819 & 0,818 & 0,147 & 0,150 & 0,148 & 0,147 \\
\hline & Austria & 0,738 & 0,738 & 0,738 & 0,738 & 0,132 & 0,139 & 0,136 & 0,132 \\
\hline & Belgium & 0,838 & 0,840 & 0,839 & 0,838 & 0,141 & 0,147 & 0,144 & 0,141 \\
\hline & Canada & 0,885 & 0,889 & 0,887 & 0,885 & 0,244 & 0,249 & 0,246 & 0,244 \\
\hline High & Denmark & 0,707 & 0,713 & 0,710 & 0,707 & 0,085 & 0,095 & 0,090 & 0,085 \\
\hline Income & Finland & 0,698 & 0,707 & 0,703 & 0,698 & 0,055 & 0,064 & 0,059 & 0,055 \\
\hline \multirow[t]{18}{*}{ Group } & France & 0,817 & 0,817 & 0,817 & 0,817 & 0,391 & 0,394 & 0,392 & 0,391 \\
\hline & Germany & 0,743 & 0,745 & 0,744 & 0,743 & 0,587 & 0,598 & 0,592 & 0,587 \\
\hline & Italy & 0,870 & 0,869 & 0,869 & 0,870 & 0,196 & 0,201 & 0,199 & 0,196 \\
\hline & Japan & 0,620 & 0,626 & 0,623 & 0,620 & 0,344 & 0,358 & 0,352 & 0,344 \\
\hline & Netherl & 0,879 & 0,883 & 0,881 & 0,879 & 0,168 & 0,175 & 0,172 & 0,168 \\
\hline & New Zeal & 0,732 & 0,735 & 0,734 & 0,732 & 0,036 & 0,039 & 0,037 & 0,036 \\
\hline & Norway & 0,747 & 0,749 & 0,749 & 0,747 & 0,048 & 0,051 & 0,050 & 0,048 \\
\hline & Singap & 0,615 & 0,631 & 0,653 & 0,672 & 0,013 & 0,016 & 0,020 & 0,024 \\
\hline & Sweden & 0,763 & 0,766 & 0,765 & 0,763 & 0,170 & 0,181 & 0,176 & 0,170 \\
\hline & Switzerl & 0,719 & 0,720 & 0,720 & 0,719 & 0,184 & 0,193 & 0,188 & 0,184 \\
\hline & UK & 0,823 & 0,824 & 0,823 & 0,823 & 0,519 & 0,528 & 0,524 & 0,519 \\
\hline & USA & 1,000 & 1,000 & 1,000 & 1,000 & 1,000 & 1,000 & 1,000 & 1,000 \\
\hline & Average & 0,765 & 0,769 & 0,769 & 0,769 & 0,204 & 0,210 & 0,207 & 0,204 \\
\hline & Brazil & 0,401 & 0,400 & 0,406 & 0,412 & 0,075 & 0,077 & 0,087 & 0,098 \\
\hline & Chile & 0,480 & 0,478 & 0,484 & 0,490 & 0,008 & 0,008 & 0,009 & 0,009 \\
\hline & Colombia & 0,374 & 0,373 & 0,378 & 0,383 & 0,005 & 0,005 & 0,006 & 0,006 \\
\hline & Greece & 0,560 & 0,567 & 0,581 & 0,590 & 0,048 & 0,062 & 0,083 & 0,105 \\
\hline & Ireland & 0,745 & 0,755 & 0,750 & 0,745 & 0,035 & 0,041 & 0,038 & 0,035 \\
\hline Medium & Israel & 0,747 & 0,753 & 0,771 & 0,788 & 0,026 & 0,027 & 0,032 & 0,037 \\
\hline Income & Korea & 0,512 & 0,522 & 0,538 & 0,553 & 0,086 & 0,098 & 0,121 & 0,145 \\
\hline \multirow[t]{13}{*}{ Group } & Mauritius & 0,516 & 0,515 & 0,522 & 0,529 & 0,000 & 0,000 & 0,000 & 0,000 \\
\hline & Mexico & 0,649 & 0,649 & 0,659 & 0,669 & 0,042 & 0,045 & 0,053 & 0,061 \\
\hline & Portugal & 0,594 & 0,602 & 0,617 & 0,630 & 0,030 & 0,039 & 0,052 & 0,066 \\
\hline & S. Africa & 0,355 & 0,353 & 0,357 & 0,362 & 0,082 & 0,079 & 0,085 & 0,092 \\
\hline & Spain & 0,756 & 0,756 & 0,756 & 0,756 & 0,127 & 0,134 & 0,131 & 0,127 \\
\hline & Thailand & 0,314 & 0,319 & 0,327 & 0,335 & 0,003 & 0,004 & 0,005 & 0,005 \\
\hline & Turkey & 0,374 & 0,383 & 0,395 & 0,406 & 0,010 & 0,013 & 0,018 & 0,023 \\
\hline & Uruguay & 0,412 & 0,408 & 0,411 & 0,415 & 0,003 & 0,003 & 0,003 & 0,003 \\
\hline & Venez & 0,599 & 0,596 & 0,604 & 0,611 & 0,023 & 0,022 & 0,024 & 0,027 \\
\hline & Average & 0,535 & 0,538 & 0,545 & 0,552 & 0,049 & 0,053 & 0,058 & 0,064 \\
\hline & Egypt & 0,431 & 0,433 & 0,441 & 0,449 & 0,008 & 0,008 & 0,009 & 0,009 \\
\hline & India & 0,199 & 0,200 & 0,204 & 0,208 & 0,029 & 0,030 & 0,035 & 0,041 \\
\hline & Kenya & 0,183 & 0,188 & 0,194 & 0,200 & 0,005 & 0,007 & 0,010 & 0,014 \\
\hline Low & Malawi & 0,132 & 0,132 & 0,134 & 0,136 & 0,007 & 0,008 & 0,010 & 0,012 \\
\hline & Pakistan & 0,257 & 0,256 & 0,259 & 0,262 & 0,005 & 0,005 & 0,005 & 0,006 \\
\hline \multirow[t]{6}{*}{ Group } & Peru & 0,316 & 0,316 & 0,322 & 0,327 & 0,003 & 0,003 & 0,004 & 0,004 \\
\hline & Philipp & 0,260 & 0,258 & 0,261 & 0,264 & 0,013 & 0,012 & 0,013 & 0,015 \\
\hline & Sri Lanka & 0,254 & 0,255 & 0,259 & 0,263 & 0,008 & 0,010 & 0,012 & 0,014 \\
\hline & Tunisia & 0,381 & 0,377 & 0,379 & 0,382 & 0,003 & 0,002 & 0,002 & 0,004 \\
\hline & Zambia & 0,158 & 0,157 & 0,159 & 0,160 & 0,001 & 0,001 & 0,001 & 0,001 \\
\hline & Average & 0,360 & 0,360 & 0,366 & 0,371 & 0,024 & 0,025 & 0,027 & 0,029 \\
\hline
\end{tabular}

Notes: See Table 4 for simulation assumptions underlying Cases 1-3.

Base Case data are "averages" over the sample period (1975-2005).

"Total Patent Stocks" include both the stocks of domestic and foreign patents. 
curs. Since the U.S. has the highest TFP and the largest total patent stock in the sample, all the individual countries' TFP and total patent stocks are divided by the TFP and total patent stock of the U.S. respectively. The average TFP among high-income countries is 0.765 of U.S. TFP; among mediumincome countries it is 0.535; and among low-income countries it is 0.360 . In Case 1, most high-income countries' TFP rises relative to U.S. TFP. The TFP gaps between the U.S. and Austria and between the U.S. and France stay constant; the gap actually widens a bit in the case of Italy. It also widens for several medium and low income countries (for example, Brazil, Chile, Tunisia, and Zambia, to name a few). The primary reason is that the U.S. is also stimulating its own TFP by strengthening its patent regime.

In Cases 2 and 3, there is somewhat greater scope for non-OECD nations to catch up in TFP levels. In Case 2, all non-OECD countries (except for Uruguay and Tunisia) experience an increase in their TFP relative to U.S. TFP. In case 3, the TFP's of all the non-OECD countries (plus Greece, Portugal, and Turkey) rise relative to that of the U.S. Some large gains are made under Case 3 by individual countries like Singapore, Korea, Portugal, and Israel. But overall the gains are modest. The average TFP among medium income countries rises from $53.5 \%$ to $55.2 \%$ of U.S. TFP, while that among low income countries rises from $36 \%$ to $37.1 \%$ of U.S. TFP.

There are several reasons why the patent reforms here produce small changes in TFP, even under case 3 (the strongest reform scenario among the simulations). The first is that the imitative capacity of medium income and low income countries is not very high; thus the value of patent protection there is relatively less. Thus even if these countries radically strengthen their patent laws, foreign patentees do not have as strong an incentive to patent there as they would if imitation risks were greater. A second reason is that patentable knowledge - that is, the measured $A$ and $A^{*}$ - fall short of true knowledge capital - that is, the theoretical $A$ and $A^{*}$. Among the omissions are tacit knowledge, knowledge that is unpatented or unpatentable (due to regulations or technicalities); knowledge from training and learning (for example, from technology transfer activities). This may be why the scientists and engineers variable shows up significantly in the TFP regression, in capturing say knowledge embodied in human capital - particularly technically trained human capital.

A third reason for the small effects on TFP has to do with the value of patents. Whereas the previous discussion focused on how patent knowledge stocks may underestimate true knowledge, another concern is that patent knowledge stocks may overestimate the usefulness of patents. Informal discussions suggest that many patents are not very valuable - that only about one in ten patents results in commercial activity. ${ }^{18}$ This would explain part of Table 5, which compares each country's total patent stock relative to that of the U.S. Typically, the average high-income country's stock

\footnotetext{
${ }^{18}$ See Blumberg (1996), for example.
} 
of total patents is about $20 \%$ of that of the U.S. - yet, despite that gap, its TFP is about $76 \%$ of that of the U.S. The same pattern emerges for the low and medium countries: the disparity in patent knowledge stocks between them and U.S. is much larger than the disparity in TFP between them and the U.S. In other words, differences in patent knowledge stocks do not appreciably account for differences in TFP. This finding is consistent with the observation that many patents may not be very 'worthy', and may help explain the low coefficient estimates of the patent knowledge stocks.

A fourth consideration is that increases in patent applications may not always be a good thing even if many involve worthy ideas. There are resource issues to consider. For instance, the more patents there are the more work imposed on patent examiners. The applications may not all be processed in a timely manner, and patent pendency (i.e. processing time) may increase, so that the time lag for patentable ideas to become part of the stock of knowledge may be higher (unless resources are expanded). The productive benefits of patent flows may therefore be delayed, so long as those very flows create congestion.

On the other hand, some criticisms can be made against the model and simulations that would suggest that the role of IPRs in explaining technology gaps has been underestimated. First, IPRs could affect TFP through other channels as well - for example, business climate - but which were not modeled. Secondly, the simulations do not allow for changes in overall innovative activity. To the extent that IPRs stimulate research and innovation, there will be more patentable ideas to file. The simulations essentially examine the filing of existing ideas (which would not be patented at the margin if the IPRs were unchanged). Furthermore, those additional patents that are stimulated are likely to be less valuable (since the more valuable ones already made the hurdle - that is, were worth patenting before IPRs were raised). Thus the model ignores the possibility that IPR reforms might stimulate new (more valuable) inventions, which are later patented. In this case, it would be necessary to know the lag between R\&D and new patents, something that is not certain. Thirdly, another weakness with the simulations is that they focus on the short run effects. It would be useful to examine the cumulative effects of maintaining higher patent standards for some longer period of time 19

Finally, a question arises about the precise meaning of large IPR changes. In what sense, for example, does case 3 constitute a major reform? Some perspective is needed on the size of these reforms. According to how the patent index was constructed, strengthening an IPR regime by 1.32 points is equivalent to making about 4.4 legal changes (e.g. ending compulsory licensing, etc.). How large these policy changes are considered to be - and ultimately how feasible or sufficient they are - should depend on how bur-

${ }^{19}$ Longer run simulations, however, should incorporate (endogenous) R\&D responses to changes in patent rights. 
densome they are. For example, what is the cost of reforming IPRs by 1.32 points? How much transitional adjustment must take place? Unless there is some idea about the cost of reform, it is difficult to say whether a patent reform is large or whether more could have been done with patent rights to close technology gaps.

\section{Concluding Remarks}

International patenting data indicate where inventions come from and where they go. This paper has utilized international patenting data to study the determinants of international patenting behavior and has also utilized them to construct international patent knowledge stocks as potential determinants of total factor productivity. The paper then focused on how changes in the strength of patent rights affect patent knowledge accumulation and the distribution of global TFP.

The issue of how patent rights affect knowledge capital accumulation and global technology gaps is often at the center of the debate on the economic effects of global intellectual property reform. Indeed, the debate continues as regional and other free trade agreements and negotiations incorporate TRIPS-plus provisions (beyond TRIPS-compliance rules), as in the current Trans Pacific Partnership (TPP) talks.

Thus the research findings in this paper should be of some relevance. The main finding is that stronger patent reforms are not likely to reduce technology gaps between the North and South very significantly, so long as patent reforms are focused on stimulating international patenting. The reason is that while patent knowledge capital is an important determinant of TFP, the measured effect on TFP is small. Hence even large changes in national stocks of patentable knowledge produce small changes in TFP, not enough for lagging countries to catch up to the leading. Some explanations for this are that patent knowledge capital captures a fraction of (true) productive knowledge and that part of patent knowledge capital is not productive. A criticism with the result is that the experiments focused on the short run impacts and that there are other effects of patent reform or of patenting that are not captured in the model (such as on business climate, bargaining power, and so forth). As an extensions to this research, it would be useful to explore alternative influences of patent rights; for example, on other kinds of knowledge capital (other than patentable knowledge), such as trade secrets, and other technology diffusion mechanisms (such as licensing and international research consortia). 


\section{References}

Bayoumi, T., Coe, D., Helpman, E., 1999. R\&D Spillovers and Global Growth. Journal of International Economics 47, 399-428. doi:10.1016/S0022-1996(98)00018-X

Blumberg, P.D., 1996. From "Publish or Perish" to "Profit or Perish": Revenues from University Technology Transfer and the Section 501(c)(3) Tax Exemption: Comment 145. University of Pennsylvania Law Review 145, 89-147.

Boisso, D., Ferrantino, M.J., 1996. Economic and Cultural Distance in International Trade: An Empirical Puzzle. U.S. International Trade Commission Working Paper.

Bosworth, D.L., 1984. Foreign Patent Flows to and from the United Kingdom. Research Policy 13, 115-124. doi:10.1016/0048-7333(84)90010-6

Computer Software Associates, Global IP Estimator: User's Guide, Oakland, California.

Connolly, M., 1997. Learning to Learn: Technological Diffusion through Trade and Imitation. Duke University, Department of Economics Working Paper No. 97-25.

Diwan, I., Rodrik, D., 1991. Patents, Appropriate Technology, and North-South Trade. Journal of International Economics 30, 27-48. doi:10.1016/0022-1996(91)90003-O

Eaton, J., Kortum, S., 1996. Trade in Ideas: Patenting and Productivity in the OECD. Journal of International Economics 40, 251-278. doi:10.1016/00221996(95)01407-1

Fagerberg, J., 1994. Technology and International Differences in Growth Rates. Journal of Economic Perspectives, 32, 1147-1175.

Ginarte, J.C., Park, W., 1997. Determinants of Patent Rights: A Cross-National Study. Research Policy. 26, 283-301. doi:10.1016/S00487333(97)00022-X

Gwartney, J., Lawson, R., 2009. Economic Freedom of the World, Fraser Institute, Vancouver, B.C.

Ham, R.M., 1999. Firm Strategy and Patent Protection in the Semiconductor Industry, Doctoral Dissertation, University of California, Berkeley, Haas School of Business.

Helfgott, S., 1993. Patent Filing Costs Around the World. Journal of the Patent and Trademark Office Society, 567-580. 
Helpman, E., 1993. Innovation, Imitation, and Intellectual Property Rights. Econometrica 61, 1247-1280. doi:10.2307/2951642

Keller, W., 2004. International Technology Diffusion. Journal of Economic Literature 42, 752-782. doi:10.1257/0022051042177685

Maskus, K., 2012. Private Rights and Public Problems: The Global Economics of Intellectual Property in the $21^{\text {st }}$ Century, Washington, DC: Peterson Institute of International Economics.

Park, W.G., 1995. International R\&D Spillovers and OECD Economic Growth. Economic Inquiry 33, 571-591. doi:10.1111/j.14657295.1995.tb01882.x

Park, W.G. 2008. International Patent Rights: An Update. Research Policy $37,761-766$.

Rivera-Batiz, L.A., Romer, P.M., 1991. International Trade with Endogenous Technological Change. European Economic Review 35, 971-1001. doi:10.1016/0014-2921(91)90048-N

Sherwood, R., 1991. Intellectual Property and Economic Development, Westview Press, Boulder, CO.

Smith, P., 1999. Are Weak Patent Rights a Barrier to U.S. Exports? Journal of International Economics, 48, 151-177. doi:10.1016/S0022-1996(98)00013-0

Summers, R., Heston, A., Aten, B., Nuxoll, D., 2005. The Penn World Tables. NBER, Cambridge, MA.

Taylor, M.S., 1994. Trips, Trade, and Growth. International Economic Review 35, 361-381. doi:10.2307/2527058

UNESCO, StatisticalYearbook, Paris, France, various issues.

van Elkan, R., 1996. Catching Up and Slowing Down: Learning and Growth Patterns in an Open Economy. Journal of International Economics 41, 95111. doi:10.1016/S0022-1996(96)01433-X

Weiss, P., 2010. Patent Policy: Legal-Economic Effects in a National and International Framework, Oxon: Routledge.

World Bank, World Development Indicators, Washington, D.C., various issues.

World Intellectual Property Office, Industrial Property Statistics: Part I, Geneva, various issues. 